\title{
Acylation of Hydrazides with Acetic Acid and Formic Acid
}

\author{
Keiko Hojo, ${ }^{a}$ Mitsuko MaedA, ${ }^{a}$ Timothy J. Smith, ${ }^{b}$ and Koichi KaWASAKI ${ }^{*}, a$ \\ Faculty of Pharmaceutical Sciences and High Technology Research Center, Kobe Gakuin University, ${ }^{a}$ Nishi-ku, Kobe \\ 651-2180, Japan and Thomas J. Long School of Pharmacy and Health Sciences, University of the Pacific, 3601 Pacific \\ Avenue, Stockton, CA 95211, U.S.A. Received September 10, 2001; accepted October 16, 2001
}

In peptide synthesis, hydrazides are important intermediates for the azide coupling method. A hydrazide is converted to the corresponding azide in the presence of an acid and a nitrite. When acetic acid (or formic acid) is used as the acid, partial acetylation (or formylation) of the hydrazide occurs as a side reaction. Formylation of the hydrazide is much faster than acetylation. Removal of the formyl group on the hydrazide with hydrazine and hydroxylamine was studied. The rate of deformylation with hydrazine treatment is faster than that with hydroxylamine treatment.

Key words hydrazide; formylation; acetylation; acylation of hydrazide; deformylation

Amino acid hydrazides are important intermediates for peptide synthesis by the azide coupling method. An $N$-protected amino acid hydrazide is converted to a corresponding azide, followed by a coupling reaction with an amino group of an amino acid to form a peptide bond. Hydrazides are also important in a Curtius rearrangement reaction as starting material for the azide. The conversion of a hydrazide to an azide is performed with a nitrite (sodium nitrite, amyl nitrite, tertbutyl nitrite, etc.) in the presence of an acid. ${ }^{1)}$ Usually, hydrochloric acid is used as the acid, but organic acids are often used. Hydrazides are also important starting materials for the preparation of $\mathrm{N}$-protected amino acid derivatives. tert-Butyloxycarbonyl (Boc) and p-methoxybenzyloxycarbonyl $[\mathrm{Z}(\mathrm{OMe})]$ amino acids were prepared by the reaction of an amino acid with the corresponding azide $\left(\right.$ Boc- $\mathrm{N}_{3}$ or $\left.\mathrm{Z}(\mathrm{OMe})-\mathrm{N}_{3}\right)$. These azides were prepared from the corresponding hydrazides (Boc-NHNH $\mathrm{N}_{2}$ or $\mathrm{Z}(\mathrm{OMe})-\mathrm{NHNH}_{2}$ ) with sodium nitrite in aqueous acetic acid. Boc- $\mathrm{N}_{3}{ }^{2)}$ was prepared in $43 \%$ acetic acid and $\mathrm{Z}(\mathrm{OMe})-\mathrm{N}_{3}{ }^{3)}$ was prepared in $45 \%$ acetic acid from each corresponding hydrazide.

Since acetic acid and formic acid have superior solubility, they are often used as both an acid and a solvent when an azide is prepared from a hydrazide with a nitrite. In these cases, especially when formic acid was used, we occasionally observed that the yield of the azide coupling reaction was poor. We speculated that the poor yield was caused by acylation on the hydrazide with the corresponding acid. The acylated hydrazide could not be converted to the azide and, as a result, the coupling yield of the azide reaction was poor. We examined acylation on a hydrazide by treatment with acetic acid and formic acid. Benzyloxycarbonylalanine hydrazide $\left(\mathrm{Z}-\mathrm{Ala}-\mathrm{NHNH}_{2}\right)$ was treated with acetic acid and the reaction mixture was examined by HPLC.

As shown in Fig. 1, a new peak was observed after treatment with acetic acid at $20^{\circ} \mathrm{C}$. Analysis of mass and NMR spectra revealed that the new peak corresponded to the acetyl derivative. After 1 and $12 \mathrm{~h}$ at $20^{\circ} \mathrm{C}, 11$ and $49 \%$ of the hydrazide was acetylated, respectively. We examined acetylation with various concentrations of acetic acid and the results are shown in Fig. 2.

The rate of acetylation was dependent upon the concentration of acetic acid. Even in aqueous 10\% acetic acid, 3\% of the hydrazide was acetylated after $1 \mathrm{~h}$.

Next, formylation of the hydrazide with formic acid was examined. As shown in Fig. 3, a new peak was observed after treatment with formic acid. The new peak was isolated and identified as the formyl derivative by time of flight mass spectra (TOF-MS) and NMR spectral analysis. After $20 \mathrm{~min}$, $60 \%$ of the hydrazide was formylated. Formylation was examined at various concentrations of formic acid and the re-

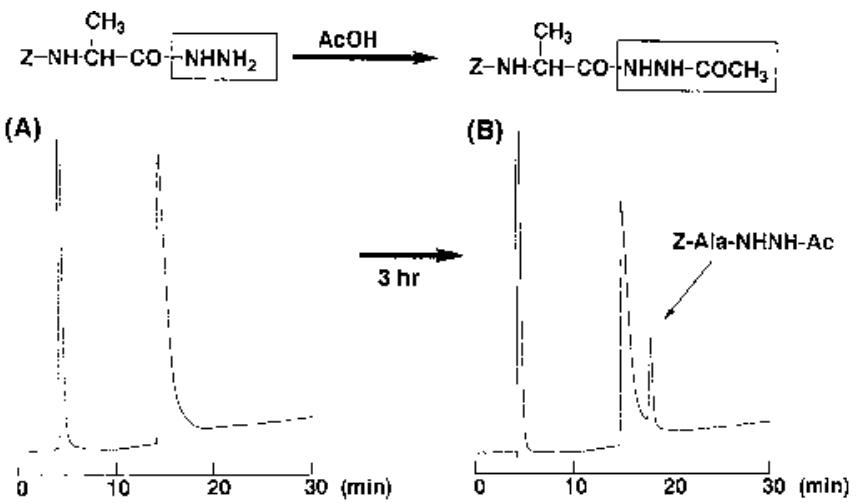

Fig. 1. HPLC Profile of Z-Ala-NHNH $\mathrm{NH}_{2}$ (A) and Z-Ala-NHNHCOCH $\mathrm{H}_{3}$ (B)

Z-Ala- $\mathrm{NHNH}_{2}$ was dissolved in $\mathrm{AcOH}$ (A) and the solution was stirred for $3 \mathrm{~h}$ (B) at $20^{\circ} \mathrm{C}$. HPLC: Column, DAISOPAK SP-120-5-ODS-B $(4.6 \times 250 \mathrm{~mm})$. Flowrate, $1 \mathrm{ml} / \mathrm{min}$. Eluent, $\mathrm{CH}_{3} \mathrm{CN} / \mathrm{H}_{2} \mathrm{O}$ containing $0.05 \% \mathrm{CF}_{3} \mathrm{COOH}$. Gradient $\left(\mathrm{CH}_{3} \mathrm{CN} / \mathrm{H}_{2} \mathrm{O}\right)$, $10 / 90 \rightarrow 50 / 50$ (40 min)

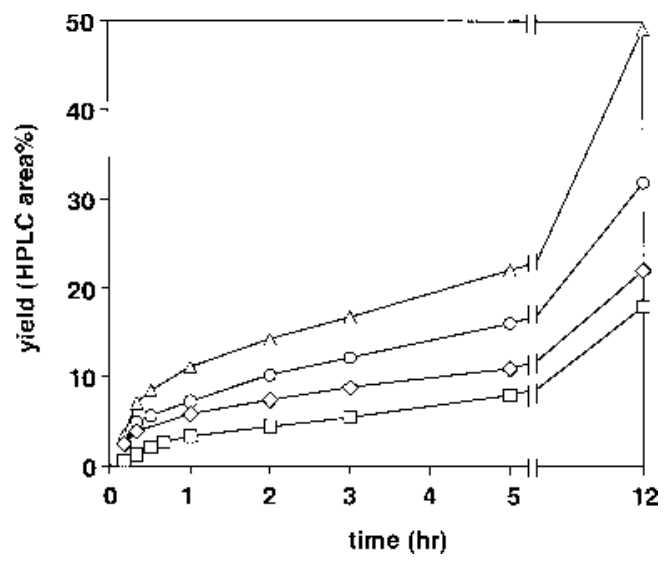

Fig. 2. Rate of Acetylation on $\mathrm{Z}-\mathrm{Ala}-\mathrm{NHNH}_{2}$ with Various Concentrations of $\mathrm{AcOH}$ at $20^{\circ} \mathrm{C}$

$\square 10 \%$ AcOH. $\diamond 25 \%$ AcOH. $\bigcirc 50 \%$ AcOH. $\triangle 100 \% \mathrm{AcOH}$. 


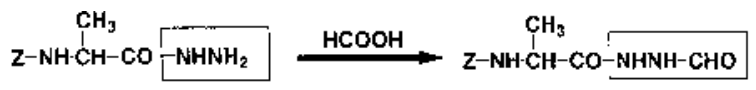

(A)

(B)

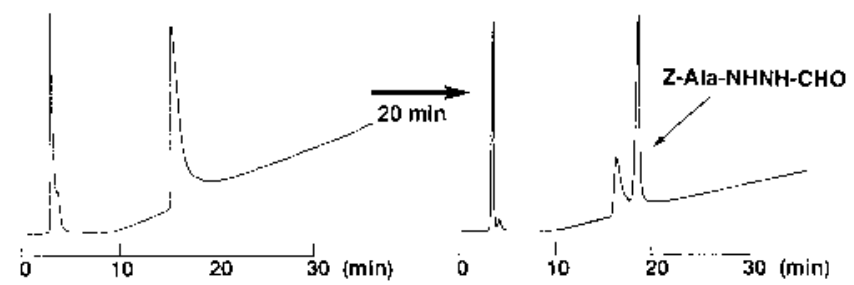

Fig. 3. HPLC Profile of Z-Ala-NHNH $\mathrm{N}_{2}$ (A) and Z-Ala-NHNHCHO (B)

Z-Ala- $\mathrm{NHNH}_{2}$ was dissolved in formic acid (A) and the solution was stirred for 20 $\min (\mathrm{B})$ at $20^{\circ} \mathrm{C}$. HPLC: Column, DAISOPAK SP-120-5-ODS-B $(4.6 \times 250 \mathrm{~mm})$. Flow rate, $1 \mathrm{ml} / \mathrm{min}$. Eluent, $\mathrm{CH}_{3} \mathrm{CN} / \mathrm{H}_{2} \mathrm{O}$ containing $0.05 \% \quad \mathrm{CF}_{3} \mathrm{COOH}$. Gradient $\left(\mathrm{CH}_{3} \mathrm{CN} / \mathrm{H}_{2} \mathrm{O}\right), 10 / 90 \rightarrow 50 / 50(40 \mathrm{~min})$.

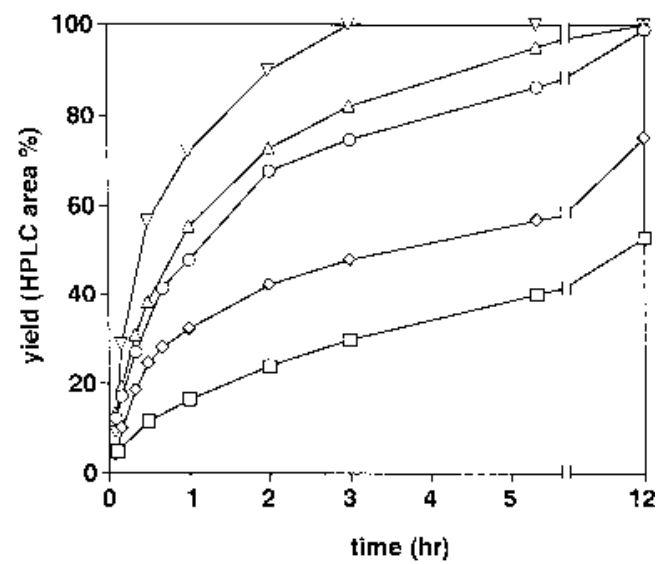

Fig. 4. Rate of Formylation on Z-Ala- $\mathrm{NHNH}_{2}$ with Various Concentrations of Formic Acid at $20^{\circ} \mathrm{C}$

$\square 5 \% \mathrm{AcOH} . \diamond 10 \% \mathrm{AcOH} . \bigcirc 25 \% \mathrm{AcOH} . \triangle 50 \% \mathrm{AcOH} . \nabla 100 \% \mathrm{AcOH}$.

sults are shown in Fig. 4.

Even at $10 \%$ concentration, $25 \%$ of the hydrazide was formylated after $30 \mathrm{~min}$.

Formylation with formic acid on the hydrazide was much faster than acetylation with acetic acid. Since formylation on a hydrazide with formic acid is not a minor side reaction, the deformylation reaction was studied to find suitable conditions for recovery of the hydrazide. Yajima et al. reported that the formyl group of $N^{\varepsilon}$-formyllysine could be removed by treatment with hydrazine or hydroxylamine. ${ }^{4)}$ Deformylation reactions with hydrazine and hydroxylamine were examined. Z-Ala-NHNHCHO was treated with a 10 equimolar concentration of hydrazine and hydroxylamine in a mixture of acetonitrile and water at 20 and $50^{\circ} \mathrm{C}$. The results are shown in Fig. 5.

As shown in Fig. 5, deformylation by hydrazine treatment is faster than that by hydroxylamine. The formyl group was removed completely at $50^{\circ} \mathrm{C}$ after $2 \mathrm{~h}$, but the deformylation reaction was slow at $20^{\circ} \mathrm{C}$. Approximately $50 \%$ of the formyl group was removed at $20^{\circ} \mathrm{C}$ after $5 \mathrm{~h}$. Since hydrazine treatment at $50^{\circ} \mathrm{C}$ might be harmful to amino acid derivatives and peptides (such as imido formation of aspartyl bond, ${ }^{5)}$ racemization, ${ }^{6}$ diketopiperazine formation, ${ }^{7)}$ etc.), acetic acid (equimolar to hydrazine hydrate) was added to reduce the $\mathrm{pH}$ of hydrazine reaction and then the mixture was

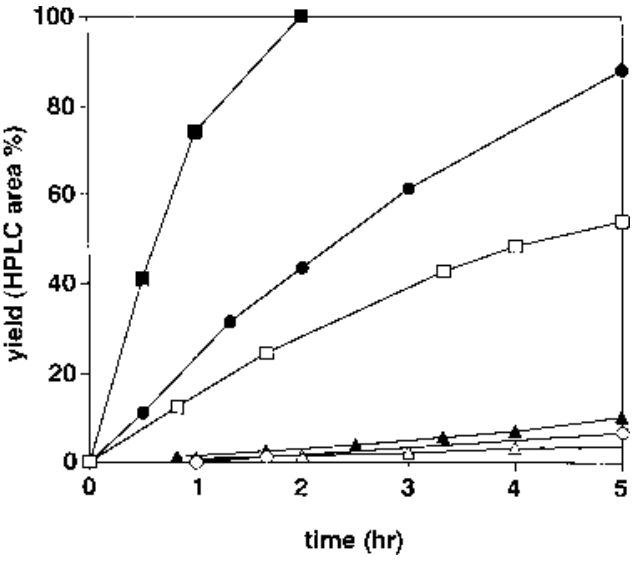

Fig. 5. Deformylation of Z-Ala-NHNHCHO with Hydrazine and Hydroxylamine

A ten molar excess of hydrazine and hydroxylamine to Z-Ala-NHNHCHO was used. - $\mathrm{NH}_{2} \mathrm{NH}_{2}, 50^{\circ} \mathrm{C}$. $\square \mathrm{NH}_{2} \mathrm{NH}_{2}, 20^{\circ} \mathrm{C}$. $\mathrm{NH}_{2} \mathrm{NH}_{2} \cdot \mathrm{AcOH}, 50^{\circ} \mathrm{C}$. $\bigcirc \mathrm{NH}_{2} \mathrm{NH}_{2} \cdot \mathrm{AcOH}$, $20^{\circ} \mathrm{C} . \Delta \mathrm{NH}_{2} \mathrm{OH}, 50^{\circ} \mathrm{C} . \triangle \mathrm{NH}_{2} \mathrm{OH}, 20^{\circ} \mathrm{C}$.

stirred at $50^{\circ} \mathrm{C}$. Deformylation with hydrazine acetate was slower than that with hydrazine. Approximately 90 and 5\% of the formyl group was removed at 50 and $20^{\circ} \mathrm{C}$, respectively, after $5 \mathrm{~h}$.

In conclusion, the rate of formylation of a hydrazide with formic acid is fast and formic acid should not be used as an acid when an azide is prepared from a hydrazide. The rate of acetylation on a hydrazide with acetic acid is relatively slow, but acetic acid should be used carefully when an azide is prepared from a hydrazide. The formyl group of a formylhydrazide is removable by hydrazine treatment. The rate of deformylation of formylhydrazide with hydrazine is more rapid than that with hydroxylamine. The rate of deformylation with hydrazine acetate is slower than that with hydrazine alone, but hydrazine acetate would be less harmful to a peptide when the peptide hydrazide is recovered from a formylated peptide hydrazide.

\section{Experimental}

The reversed-phase (RP)-HPLC was conducted with a Waters 600 on a DAISOPAK column using gradient systems of $\mathrm{CH}_{3} \mathrm{CN} / \mathrm{H}_{2} \mathrm{O}$ containing $0.05 \%$ trifluoroacetic acid. TOF-MS were measured with a Shimadzu/Kratos Kompact MALDI IV mass spectrometer.

Formic Acid Treatment of Z-Ala-NHNH 2 Z-Ala-NHNH $2(100 \mathrm{mg}$, $0.42 \mathrm{mmol}$ ) was dissolved in a mixture of $\mathrm{CH}_{3} \mathrm{CN}$ and $\mathrm{H}_{2} \mathrm{O}(1 / 1)$ and formic acid was added to the solution to prepare various formic acid concentrations. The total volume was adjusted to $2 \mathrm{ml}$ by addition of $\mathrm{CH}_{3} \mathrm{CN} / \mathrm{H}_{2} \mathrm{O}(1 / 1)$. The solution was stirred at $20^{\circ} \mathrm{C}$ and portions were removed periodically for analysis by HPLC.

Acetic Acid Treatment of Z-Ala-NHNH 2 Performed as described above with acetic acid instead of formic acid.

Z-Ala-NHNHCHO Z-Ala-NHNH $2(100 \mathrm{mg}, 0.42 \mathrm{mmol})$ was dissolved in formic acid $(2 \mathrm{ml})$ and the solution was kept at $20^{\circ} \mathrm{C}$ for $3 \mathrm{~h}$. The formic acid was removed in vacuo and the residue was recrystallized from $\mathrm{CH}_{3} \mathrm{CN}$. Yield $83 \mathrm{mg}(82 \%)$, mp $178^{\circ} \mathrm{C}$. $[\alpha]_{\mathrm{D}}^{25}-37.7^{\circ}(c=1.0,75 \%$ $\mathrm{CH}_{3} \mathrm{CN} / \mathrm{H}_{2} \mathrm{O}$ ). Anal. Calcd for $\mathrm{C}_{12} \mathrm{H}_{15} \mathrm{~N}_{3} \mathrm{O}_{4}: \mathrm{C}, 54.3 ; \mathrm{H}, 5.7 ; \mathrm{N}, 15.8$. Found: $\mathrm{C}, 54.1 ; \mathrm{H}, 5.6 ; \mathrm{N}, 15.8 .{ }^{1} \mathrm{H}-\mathrm{NMR}(400 \mathrm{MHz}) \delta: 9.97(2 \mathrm{H}, \mathrm{brs}, \mathrm{NHNH})$, $7.98(1 \mathrm{H}, \mathrm{s}, \mathrm{CHO}), 7.34(5 \mathrm{H}, \mathrm{m}, \mathrm{Ar}-\mathrm{H}), 5.05\left(2 \mathrm{H}, \mathrm{s}, \mathrm{Ar}_{-} \mathrm{CH}_{2}-\mathrm{OCO}\right), 4.09$ $(1 \mathrm{H}, \mathrm{q}, J=7 \mathrm{~Hz}, \alpha-\mathrm{CH}), 3.30(1 \mathrm{H}, \mathrm{br}, \mathrm{CONH}), 1.23\left(3 \mathrm{H}, \mathrm{d}, J=7 \mathrm{~Hz}, \mathrm{CH}_{3}-\right.$ C ). TOF-MS $m / z: 288.97(\mathrm{M}+\mathrm{Na})^{+}$.

Z-Ala-NHNHCOCH $\mathrm{C}_{3}$ Z-Ala-NHNH ${ }_{2}(100 \mathrm{mg}, 0.42 \mathrm{mmol})$ was dissolved in acetic acid $(2 \mathrm{ml})$ and the solution was kept at $20^{\circ} \mathrm{C}$ for $2 \mathrm{~d}$. The acetic acid was removed in vacuo and the residue was recrystallized from $\mathrm{CH}_{3} \mathrm{CN}$. Yield $82 \mathrm{mg}(78 \%), \mathrm{mp} 181{ }^{\circ} \mathrm{C}$. $[\alpha]_{\mathrm{D}}^{25}-24.2^{\circ}(c=1.0,75 \%$ $\mathrm{CH}_{3} \mathrm{CN} / \mathrm{H}_{2} \mathrm{O}$ ). Anal. Calcd for $\mathrm{C}_{13} \mathrm{H}_{17} \mathrm{~N}_{3} \mathrm{O}_{4}: \mathrm{C}, 55.9 ; \mathrm{H}, 6.1 ; \mathrm{N}, 15.1$. Found: $\mathrm{C}, 55.9 ; \mathrm{H}, 6.1 ; \mathrm{N}, 15.0 .{ }^{1} \mathrm{H}-\mathrm{NMR}(400 \mathrm{MHz}) \delta: 9.76(2 \mathrm{H}, \mathrm{brs}, \mathrm{NHNH})$, 
$7.34(5 \mathrm{H}, \mathrm{m}, \mathrm{Ar}-\mathrm{H}), 5.00\left(2 \mathrm{H}, \mathrm{s}, \mathrm{Ar}-\mathrm{CH}_{2}-\mathrm{OCO}\right), 4.10(1 \mathrm{H}, \mathrm{q}, J=7 \mathrm{~Hz}, \alpha-$ $\mathrm{CH}), 3.30(1 \mathrm{H}$, br s, $\mathrm{CONH}), 1.82\left(3 \mathrm{H}, \mathrm{s}, \mathrm{CH}_{3}-\mathrm{CO}\right), 1.23(3 \mathrm{H}, \mathrm{d}, J=7 \mathrm{~Hz}$, $\left.\mathrm{CH}_{3}-\mathrm{C}\right)$. TOF-MS $m / z: 302.65(\mathrm{M}+\mathrm{Na})^{+}$.

Treatment of Z-Ala-NHNHCHO with Hydrazine Hydrate Z-AlaNHNHCHO $(100 \mathrm{mg}, 0.38 \mathrm{mmol})$ was dissolved in a mixture of $\mathrm{CH}_{3} \mathrm{CN}$ and $\mathrm{H}_{2} \mathrm{O}(1 / 1,3 \mathrm{ml})$. Hydrazine hydrate $(10 \mathrm{eq})$ [or hydrazine hydrate $(10$ eq) $+\mathrm{AcOH}(10 \mathrm{eq})]$ was added to the solution and the entire mixture was stirred at $20^{\circ} \mathrm{C}$ (or $50^{\circ} \mathrm{C}$ ). Portions were removed periodically for analysis by HPLC. A new peak appeared and its retention time was identified with that of Z-Ala- $\mathrm{NHNH}_{2}$. The mass spectrum of the material in the new peak corresponded to Z-Ala-NHNH ${ }_{2}$. TOF-MS $m / z 238.45(\mathrm{M}+1)^{+}$.

Treatment of Z-Ala-NHNHCHO with Hydroxylamine Z-AlaNHNHCHO $(100 \mathrm{mg}, 0.38 \mathrm{mmol})$ was dissolved in a mixture of $\mathrm{CH}_{3} \mathrm{CN}$ and $\mathrm{H}_{2} \mathrm{O}(1 / 1,3 \mathrm{ml})$. Hydroxylamine hydrochloride (10 eq) was added to the solution and the mixture adjusted to $\mathrm{pH} 8$ by adding triethylamine. The entire reaction mixture was stirred at $20^{\circ} \mathrm{C}$ (or $50^{\circ} \mathrm{C}$ ) and portions were removed periodically for analysis by HPLC. A new peak appeared and its retention time was identified with that of Z-Ala- $\mathrm{NHNH}_{2}$. The mass spectrum of the material in the new peak corresponded to Z-Ala-NHNH 2 . TOF-MS $\mathrm{m} / \mathrm{z}$
$238.45(\mathrm{M}+1)^{+}$

\section{References}

1) a) Curtius T., Ber. Dtsch. Chem. Ges., 35, 3226-3228 (1902); b) Honzl H., Rudinger J., Collect. Czech. Chem. Commun., 26, 23332344 (1961).

2) Carpino L. A., J. Am. Chem. Soc., 82, 2725-2727 (1960); Schwyzer R., Sieber P., Kappeler H., Helv. Chim. Acta, 42, 2622-2624 (1959).

3) Weygand F., Hunger K., Chem. Ber., 95, $1-6$ (1962).

4) Yajima H., Kawasaki K., Okada Y., Minami H., Kubo K., Yamashita I., Chem. Pharm. Bull., 16, 919-928 (1968).

5) Bodanszky M., Kwei T., Int. J. Peptide Protein Res., 12, 69-74 (1978).

6) Kemp D. S., "Racemization in Peptide Synthesis in The Peptides," Vol. 1, ed. by Gross E., Meienhofer J., Academic Press, New York, 1979, pp. $315-383$.

7) Geiger R., König W., "Side Reaction of Amide Group in the Peptides," Vol. 3, ed. by Gross E., Meienhofer J., Academic Press, New York, 1981, pp. $50-53$. 